http://dx.doi.org/10.11646/phytotaxa.164.1.2

\title{
Phylogeny and taxonomy of Ceriporiopsis (Polyporales) with descriptions of two new species from southern China
}

\author{
CHANG-LIN ZHAO \& BAO-KAI CUI* \\ Institute of Microbiology, PO Box 61, Beijing Forestry University, Beijing 100083, China \\ *Corresponding author's e-mail: baokaicui2013@gmail.com
}

\begin{abstract}
Phylogenies of Ceriporiopsis and related genera were studied using DNA sequences from the ITS $+28 \mathrm{~S}$ nuclear ribosomal RNA gene regions. Two species, Ceriporiopsis alboaurantia and C. semisupina, are described as new to science. Ceriporiopsis alboaurantia is characterized by annual growth habit, resupinate basidiocarps with white pore surface when fresh, turning to apricot-orange to dark orange upon drying, monomitic hyphal system with clamped generative hyphae encrusted with pale yellow crystals, ellipsoid and thin-walled basidiospores $(4-5 \times 3-3.3 \mu \mathrm{m})$, and plenty of pale-yellow to pale-orange oily substances in subiculum and trama. Ceriporiopsis semisupina is distinguished by annual, effused-reflexed basidiocarps with greyish brown to reddish brown pore surface, monomitic hyphal system with clamped generative hyphae bearing crystalline incrustation, long-clavate basidia, ellipsoid and thin-walled basidiospores $(4-4.5 \times 3-3.3 \mu \mathrm{m})$. Like previous study, the phylogenetic analysis presented here also showed that Ceriporiopsis is not monophyletic and the sampled species were grouped in four clades, including phlebia clade, residual polyporoid clade, tyromyces clade and gelatoporia clade.
\end{abstract}

Key words: Phanerochaetaceae, polypore, wood-rotting fungi

\section{Introduction}

Ceriporiopsis Domański (Phanerochaetaceae, Polyporales) was typified by C. gilvescens (Bres.) Domański. It is characterized by a combination of annual, resupinate basidiocarps, monomitic hyphal structure with clamp connections, and subcylindrical to ellipsoid basidiospores. This combination is not uncommon for many polypores and is likely homoplasious. In addition, its hyphae and spores are acyanophilous and negative in Melzer's reagent. It is a cosmopolitan genus occurring in temperate, boreal, and tropical areas, and causing white rot (Gilbertson \& Ryvarden 1986, Ryvarden \& Gilbertson 1993, Núñez \& Ryvarden 2001).

Lack of robust morphological features for the genus has resulted in a number of names combined under Ceriporiopsis generic name. The MycoBank database (http://www.mycobank.org) includes 64 specific and infraspecific names in Ceriporiopsis and Index Fungorum (http://www.indexfungorum.org) registers 61 ones, but some species were transferred to other genera according to the Index Fungorum database, and the actual number of species is much lower; until now about 30 species were recognized by polypore specialists in the genus worldwide (Hattori 2002, Bernicchia \& Ryvarden 2003, Kinnunen \& Niemelä 2005, Fortey \& Ryvarden 2007, Læssøe \& Ryvarden 2010, Tomšovský et al. 2010, Vlasák et al. 2012, Cui 2013).

Recently, molecular study employing multi-gene datasets by Binder et al. (2013) has helped to clarify the generic relationships of polyporoid fungi and to provide phylogenetic overview of the Polyporales. They demonstrated that the type species of Ceriporiopsis (C. gilvescens) belongs to the phlebioid clade, but appeared to be grouped with smooth, merulioid and hydnaceous genera, such as Ceraceomyces Jülich, Ceriporia Donk, Gloeoporus Mont., Merulius Haller, Mycoacia Donk, Phanerochaete P. Karst. and Phlebia Fr. Phylogenetic study of European Ceriporiopsis taxa inferred from the combined data of the large subunit nuclear rRNA gene (nLSU) and mitochondrial small subunit rRNA (mtSSU) gene sequences, suggested that 1) the genus is polyphyletic, 2) the type Ceriporiopsis gilvescens was grouped with Phlebia spp., 3) the taxa of Ceriporiopsis s.l. (Tomšovský et al. 
In gelatoporia clade, Poria subvermispora Pilát was combined in Gloeoporus by Eriksson (1958) based on its resupinate basidiocarps and monomitic hyphal system. Later Niemelä (1985) transferred it to the genus Gelatoporia for its acyanophilous hyphae and allantoid basidiospores. Gilbertson \& Ryvarden (1985) put it into Ceriporiopsis by its resupinate basidiocarps with white to pale cream pore surface. Tomšovský et al. (2010) revealed that the taxon belongs to the phlebia clade, and put it into Gelatoporia. However, recent phylogenetic studies showed that it clustered into the gelatoporia clade (Miettinen \& Rajchenberg 2012, Binder 2013). Our research also showed that it is clustered in a separate gelatoporia clade (Fig. 1). Morphologically, Gelatoporia subvermispora (Pilát) Niemelä differs from Ceriporiopsis alboaurantia and C. semisupina by having allantoid basidiospores (Niemelä 1985).

\section{Acknowledgements}

The authors are grateful to Drs. Josef Vlasák (České Budějovice, Czech Republic) and Karl-Henrik Larsson (O, Norway) for loan of specimens. The research was financed by Beijing Higher Education Young Elite Teacher Project (Project No. YETP0774) and the Fundamental Research Funds for the Central Universities (Project No. JC2013-1).

\section{References}

Bernicchia, A. \& Ryvarden, L. (2003) A new polypore species (Basidiomycetes), Ceriporiopsis guidella, is described from northern Italy. Mycotaxon 88: 219-224.

Binder, M., Justo, A., Riley, R., Salamov, A., López-Giráldez, F., Sjökvist, E., Copeland, A., Foster, B., Sun, H., Larsson, E., Larsson, K.H., Townsend, J., Grigoriev, I.V. \& Hibbett, D.S. (2013) Phylogenetic and phylogenomic overview of the Polyporales. Mycologia 105: 1350-1373. http://dx.doi.org/10.3852/13-003

Cui, B.K. (2013) Two new polypores (Ceriporiopsis lavendula and Skeletocutis inflata spp. nov.) from Guangdong Province, China. Nordic Journal of Botany 31: 326-330. http://dx.doi.org/10.1111/j.1756-1051.2012.01674.x

Cui, B.K. \& Dai, Y.C. (2013) Molecular phylogeny and morphology reveal a new species of Amyloporia (Basidiomycota) from China. Antonie van Leeuwenhoek 104: 817-827. http://dx.doi.org/10.1007/s10482-013-9994-1

Cui, B.K. \& Decock, C. (2013) Phellinus castanopsidis sp. nov. (Hymenochaetaceae) from southern China, with preliminary phylogeny based on rDNA sequences. Mycological Progress 12: 341-351. http://dx.doi.org/10.1007/s11557-012-0839-5

Cui, B.K., Dai, Y.C. \& Bao, H.Y. (2009) Wood-inhabiting fungi in southern China 3. A new species of Phellinus (Hymenochaetales) from tropical China. Mycotaxon 110: 125-130. http://dx.doi.org/10.5248/110.125

Cui, B.K., Du, P. \& Dai, Y.C. (2011) Three new species of Inonotus (Basidiomycota, Hymenochaetaceae) from China. Mycological Progress 10: 107-114. http://dx.doi.org/10.1007/s11557-010-0681-6

Dai, Y.C. (2010) Hymenochaetaceae (Basidiomycota) in China. Fungal Diversity 45: 131-343. http://dx.doi.org/10.1007/s13225-010-0066-9

Dai, Y.C. (2012) Polypore diversity in China with an annotated checklist of Chinese polypores. Mycoscience 53: 49-80. http://dx.doi.org/10.1007/s10267-011-0134-3

Dai, Y.C., Cui, B.K. \& Liu, X.Y. (2010) Bondarzewia podocarpi, a new and remarkable polypore from tropical China. Mycologia 102: 881-886. http://dx.doi.org/10.3852/09-050

Dai, Y.C., Cui, B.K., Yuan, H.S., He, S.H., Wei, Y.L., Qin, W.M., Zhou, L.W. \& Li, H.J. (2011) Wood-inhabiting fungi in southern China 4. Polypores from Hainan Province. Annales Botanici Fennici 48: 219-231. http://dx.doi.org/10.5735/085.048.0302

Dai, Y.C., Niemelä, T. \& Kinnunen, J. (2002) The polypore genera Abundisporus and Perenniporia (Basidiomycota) in China, with notes on Haploporus. Annales Botanici Fennici 39: 169-182.

Dai, Y.C., Yu, C.J. \& Wang, H.C. (2007) Polypores from eastern Xizang (Tibet), western China. Annales Botanici Fennici 44: $135-145$.

Du, P. \& Cui, B.K. (2009) Two new species of Megasporoporia (Polyporales, Basidiomycota) from tropical China. Mycotaxon 110: 131-138.

http://dx.doi.org/ 10.5248/110.131 
Eriksson, J. (1958) Studies in the Heterobasidiomycetes and Homobasidiomycetes-Aphyllophorales of Muddus National Park in North Sweden. Symbolae Botanicae Upsalienses 16: 1-172.

Felsenstein, J. (1985) Confidence intervals on phylogenetics: an approach using bootstrap. Evolution 39: $783-791$. http://dx.doi.org/10.2307/2408678

Fortey, R.A. \& Ryvarden, L. (2007) Ceriporiopsis herbicola (Polyporaceae, Basidiomycota). Synopsis Fungorum 23: $13-14$.

Gilbertson, R.L. \& Ryvarden, L. (1985) Some new combinations in the Polyporaceae. Mycotaxon 22: 363-365.

Gilbertson, R.L. \& Ryvarden, L. (1986) North American polypores 1. Fungiflora, Oslo.

Hall, T.A. (1999) Bioedit: a user-friendly biological sequence alignment editor and analysis program for Windows 95/98/NT. Nucleic Acids Symposium Series 41: 95-98.

Hattori, T. (2002) Type studies of the polypores described by E.J.H. Corner from Asia and West Pacific areas. IV. Species described in Tyromyces (1). Mycoscience 43: 307-315. http://dx.doi.org/10.1007/S102670200045

Kinnunen, J. \& Niemelä, T. (2005) North European species of Ceriporiopsis (Basidiomycota) and their Asian relatives. Karstenia 45: 81-90.

Læssøe, T. \& Ryvarden, L. (2010) Studies in neotropical polypores 26. Some new and rarely recorded polypores from Ecuador. Synopsis Fungorum 27: 34-58.

Li, H.J. \& Cui, B.K. (2013) Taxonomy and phylogeny of the genus Megasporoporia and its related genera. Mycologia 105: 368-383. http://dx.doi.org/10.3852/12-114

Miettinen, O. \& Rajchenberg, M. (2012) Obba and Sebipora, new polypore genera related to Cinereomyces and Gelatoporia (Polyporales, Basidiomycota). Mycological Progress 11: 131-147. http://dx.doi.org/10.1007/s11557-010-0736-8

Moreno, G., Blanco, M.N., Checa, J., Platas, G. \& Peláez, F. (2011) Taxonomic and phylogenetic revision of three rare irpicoid species within Meruliaceae. Mycological Progress 10: 481-491. http://dx.doi.org/10.1007/s11557-010-0717-y

Nakasone, K.K. (2002) Mycoaciella, a synonym of Phlebia. Mycotaxon 81: 477-490.

Niemelä, T. (1985) On Fennoscandian polypores 9. Gelatoporia n. gen. and Tyromyces canadensis, plus notes on Skeletocutis and Antrodia. Karstenia 25: 21-40.

Núñez, M. \& Ryvarden, L. (2001) East Asian polypores 2. Synopsis Fungorum 14: 165-522.

Nylander, J.A.A. (2004) MrModeltest v2. Program distributed by the author. Evolutionary Biology Centre, Uppsala University.

Parmasto, E. \& Hallenberg, N. (2000) A taxonomic study of phlebioid fungi (Basidiomycota). Nordic Journal of Botany 20: $105-118$. http://dx.doi.org/10.1111/j.1756-1051.2000.tb00740.x

Petersen, J.H. (1996) Farvekort. The Danish Mycological Society's colour-chart. Foreningen til Svampekundskabens Fremme, Greve. 6 pp.

Posada, D. \& Crandall, K.A. (1998) Modeltest: Testing the model of DNA substitution. Bioinformatics 14: 817-818. http://dx.doi.org/10.1093/bioinformatics/14.9.817

Ronquist, F. \& Huelsenbeck, J.P. (2003) MrBayes 3: bayesian phylogenetic inference under mixed models. Bioinformatics 19: 1572-1574. http://dx.doi.org/10.1093/bioinformatics/btg180

Ryvarden, L. \& Gilbertson, R.L. (1993) European polypores 1. Synopsis Fungorum 6: 1-387.

Swofford, D.L. (2002) PAUP*: Phylogenetic analysis using parsimony (*and other methods). Version 4.0b10. Sinauer Associates, Massachusetts.

Thompson, J.D., Gibson, T.J., Plewniak, F., Jeanmougin, F. \& Higgins, D.G. (1997) The CLUSTAL X windows interface: flexible strategies for multiple sequence alignment aided by quality analysis tools. Nucleic Acids Research 25: 4876-4882. http://dx.doi.org/10.1093/nar/25.24.4876

Tomšovský, M., Menkis, A. \& Vasaitis, R. (2010) Phylogenetic relationships in European Ceriporiopsis species inferred from nuclear and mitochondrial ribosomal DNA sequences. Fungal Biology 114: 350-358. http://dx.doi.org/10.1016/j.funbio.2010.02.004

Vlasák, J., Vlasák, J.J. \& Ryvarden, L. (2012) Four new polypore species from the western United States. Mycotaxon 119: $217-$ 231. http://dx.doi.org/10.5248/119.217

White, T.J., Bruns, T., Lee, S. \& Taylor, J. (1990) Amplification and direct sequencing of fungal ribosomal RNA genes for phylogenetics. In: PCR Protocols: A guide to methods and applications (eds. MA Innis, DH Gelfand, JJ Sninsky and TJ White). Academic Press, San Diego, pp. 315-322.

Zhao, C.L. \& Cui, B.K. (2013) Truncospora macrospora sp. nov. (Polyporales) from Southwest China based on morphological and molecular data. Phytotaxa 87: 30-38. http://dx.doi.org/10.11646/phytotaxa.87.2.2

Zhao, C.L., Cui, B.K. \& Dai, Y.C. (2013) New species and phylogeny of Perenniporia based on morphological and molecular characters. Fungal Diversity 58: 47-60. http://dx.doi.org/10.1007/s13225-012-0177-6 